\title{
Strategies of valuation: repertoires of worth at the financial margins
}

\author{
Anya Degenshein ${ }^{1}$
}

Published online: 27 September 2017

(C) Springer Science+Business Media B.V. 2017

\begin{abstract}
This article draws upon thirteen months of ethnographic research in a Chicago pawnshop to show how prices of objects in pawnshops are actively, socially negotiated using what I term discursive strategies of valuation. Three kinds of discursive strategies of valuation emerge repeatedly in the data: a. references to the specific material attributes of the objects, b. references to the unique biographical histories of the objects, c. reference to the financial need and (relative) social positioning of the customer involved in the negotiation. Examining these strategies reveals the relationship between socially contingent and culturally constructed perceptions of value and the production of price. I find that rhetorical strategies can and do affect price, within limits. Perhaps most surprisingly, the data show that discursive strategies emphasizing a lower socio-economic status can inflate the value, and ultimately the price, of an object during negotiations.
\end{abstract}

Keywords Cultural objects · Discursive strategies · Fringe banking · Pawnshops · Pricing · Valuation

A discursive formation will be individualized if one can define the system of formation of the different strategies that are deployed in it; in other words, if one can show how they all derive (in spite of their sometimes extreme diversity, and in spite of their dispersion in time) from the same set of relations.

- Michel Foucault, The Archeology of Knowledge (2010, p. 68)

A sign in the window of Second City Pawn, ${ }^{1}$ a pawnshop on the North Side of Chicago, proclaims that the store deals in "Anything of Value." To the average passerby

\footnotetext{
${ }^{1}$ Names of people and places have been changed to protect the identities of research subjects; locations have also been obscured.
}

Anya Degenshein

adegenshein@u.northwestern.edu

1 Department of Sociology, Northwestern University, 1812 Chicago Ave, Evanston, IL 60208, USA 
who has a basic understanding of pawnshops, this declaration may seem banal or sufficiently intuitive at the very least. But to anyone who steps inside the shop and participates in or observes a transaction, the questions of what, exactly, is of value to the store, and more importantly, how those values are determined, become the crucial puzzles and social processes on which all financial transactions in the pawnshop depend.

This article begins with those very inquiries, asking how price, informed by competing schemas and processes of valuation, is determined for objects pawned, sold to, and bought from a Chicago pawnshop. Motivated by previous work that has detailed the social nature of value (Zelizer 1985, 1994, 2004, 2005; Smith 1989; Wherry and Crosby 2011; Wherry 2012; Stallybrass 2001; Appadurai 1986; Kopytoff 1986) as well as price setting (Velthuis 2003; Wherry 2008; Aspers and Beckert 2011; Beckert 2011), I draw here upon thirteen months of ethnographic research in a Chicago pawnshop to examine the interactive, rhetorical strategies employed by customers and employees alike to contest and, if successful, produce the price assigned to a particular object in the shop. These speech tactics, which I call discursive strategies of valuation, are used to negotiate the market price of objects pawned, sold to, and bought from pawnshops. This is accomplished through patterned, rhetorical scripts meant to highlight a specific kind of value attributed to the object or to the social relations at the moment of negotiation. These discursive strategies reveal how competing notions of value vie to set market prices within an institutionally bounded context, beholden to local demand, national market price, and institutional policies and regulations. In other words, within a range with set maximum and minimum market values, the discursive strategies have the ability to challenge and construct market prices for objects in the store by drawing upon culturally dependent meanings and noneconomic forms of value. Thus, these speech strategies are routinely used by both customers and employees to challenge, justify, and alter the particular monetary value one party has assigned to a given object.

The key questions I therefore ask are, how is the negotiation of value enacted in the pawnshop and what does this negotiation contribute to our understanding of the social nature of value? Further, what kinds of rhetorical strategies do employees and customers use to negotiate object values? Finally, how are the larger cultural, structural, and relational conditions that exist outside of the pawnshop used in valuation processes within the shop? Of particular interest to this last question is the effect of a lower socioeconomic status on access to financial instruments.

In agreement with the current sociological literature on valuation, I find that market values are actively and socially constructed within institutional contexts. More specifically, the process of pawning (or selling) one's possessions reveals the social relativity of value, dependent upon one's understanding of the object as well as to the other party involved in the negotiation. However, by emphasizing the patterned discursive strategies used in the negotiation process rather than the "real" social conditions of the relationships involved, I reveal the sometimes surprising ways asymmetric social knowledge and positioning can be mobilized to benefit the party assumed to be disadvantaged in the negotiation.

Three patterns of discursive strategies repeatedly emerge in the data. These patterns include references to specific material attributes of objects, the unique biographical histories embodied in each object that convey past use, and, perhaps most surprisingly, drawing upon the financial need and relative social positioning of the customers as salient conditions that produce moral obligation to help (temporarily) mitigate. Using these strategies as signposts, price setting in the pawnshop can thereby be seen as the explicitly 
social process it is, rather than mistaken for an objective market- (or expert-) determined process. Moreover, these patterns illuminate the shared understanding of both the legitimacy of certain kinds of extra-monetary value (as in the first two cases), as well as the socio-economic conditions that necessitate the very existence of the pawnshop (as in the last case). However, while these shared understandings inform negotiations, they in no way predetermine outcomes. Indeed, focusing on the discourse used in the bargaining process ultimately allows us to see how asymmetries in knowledge and social status inform the rhetorical scripts available in any given transactional context, but also how these same asymmetries may lead to counterintuitive advantages in a financial transaction.

This article begins with an overview of the existing literatures and supporting theoretical frames from which the research builds upon. It then proceeds to a brief overview and justification of the methodological approach. Subsequently, I turn to data analysis and findings, examining the three patterns of discursive strategies of valuation at length. I conclude with a discussion of the findings and their potential significance for future research as well as for challenging particular assumptions about the role of discursive strategies in the mainstream-banking sector and beyond.

\section{Valuation, price-setting, and the economy of a pawnshop}

Pawnshops are part of a network of businesses referred to collectively as Alternative Financial Services, or more colloquially as the "fringe economy," whose annual transactions are estimated to be more than $\$ 320$ billion (Bradley et al. 2009; Degenshein 2016). ${ }^{2}$ These legal businesses include a variety of services, including money orders, prepaid cards, and non-bank check cashing; but among the subset that offer short-term cash loans, including auto title loans and payday lenders, pawnshops have particular significance. To begin, pawning in the United States dates back to the seventeenth century and has served as an important credit source for citizens locked out of mainstream banking options since the eighteenth century (Woloson 2007, 2012; Marron 2009; Caskey 1994; McCants 2007; Tebbutt 1983). But even today, with expanded alternative loan options, pawnshops are the most commonly used form of alternative credit, with just under $3 \%$ of all US households using a pawnshop at least once in $2013^{3}$ (FDIC 2014). While this may not seem particularly significant, the next most popular form of alternative credit, namely payday loans, was used by only $2 \%$ of all households in 2013 (FDIC 2014) despite the fact that the Consumer Financial Protection Bureau has recently enacted legislation to help regulate the payday lending industry specifically (Cowley 2016; Degenshein 2016).

Further, unlike payday loans and other non-secured, alternative cash loans, pawnshops do not require customers to have a bank account or a steady stream of income, and neither run a customer credit check nor affect a customer's credit regardless of the transaction

\footnotetext{
${ }^{2}$ According to Bradley et al., this estimate was likely understated at the time of report in 2009 since it was not current then and did not include all Alternative Financial Services; the figure is now that much more likely to be underestimated.

${ }^{3}$ Unfortunately the FDIC only began collecting biennial, national, survey-based data on pawnshop and other alternative banking usage in 2009, so while we know that usage rates have remained quite constant since 2009, we do not have an earlier point of comparison.
} 
outcome. Instead, to mitigate financial risk and broaden social access to credit, the pawnshop relies upon the use of collateral — an object deemed to have a particular market value by the store - to secure all loans. The collateral, moreover, cannot be sold or disposed of by the shop so long as the loan is active, accomplished through timely payments of monthly interest and fees. The collateral thereby enables the pawnshop to forego the use of credit scores, bank account balances, and employment status - the primary tools mainstream banks use to help mitigate risk when extending loans (Marron 2009; Caskey 1994; Karger 2005). It is therefore unsurprising that pawnshop customers are disproportionately poorer, people of color, women, and with lower education (FDIC 2014, 2012), all groups who have traditionally faced greater barriers to economic success than their higher SES, white, male counterparts (Massey 2007; Woloson 2007; Marron 2009).

Pawnshops as banking institutions in the United States are also distinguished by the fact that one is able to buy and sell used goods at the very same site - and during the very same visit — where one can procure a loan, broadening the scope of economic transactions in the same institutional space. ${ }^{4}$ Pawnshops are further set apart from mainstream consumer credit by the distinct set of federal and (mostly) state regulations that govern pawnshops as well as other fringe banking outfits such as check cashing businesses and payday loan centers (Caskey 1994; see also, Illinois Pawnbroker Regulation Act from the Illinois General Assembly 2013). Importantly, pawnshops are allowed to charge higher rates of interest and fees than mainstream credit-lending institutions. Indeed, it is supposed "risk" that justifies a 20\% monthly (average) interest rate, or a non-compounded annual percentage rate (APR) of $240 \%$, in Chicago, further penalizing the already disproportionately marginalized groups that use pawnshops (Karger 2005; Caskey 1994). ${ }^{5}$

\footnotetext{
${ }^{4}$ This stands in contrast to the French model, for example, where objects that are defaulted on can only be purchased once a year at a large, public auction. Further, the interior of the French pawnshop looks more like a U.S. bank or payday-lending outfit, with no objects on display. Additionally, the French model does not buy used items to then turn over and resell; all objects that come through the business are used as collateral for a loan. See Baum (2008) for more information.

${ }_{5}^{5}$ Pawnshops have a long and important history in many other countries around the world as well, yet the rules and regulations for pawn brokering differ substantially from country-to-country. For example, in addition to the differences previously pointed out between the French and American models, French pawnshops are also publicly owned and operated. According to Baum (2008), the major Parisian pawnshop, the Credit Municipal, has been owned and operated by the city since the eighteenth century. Loans are all for 12 month periods and are indefinitely renewable, at an annual interest rate of $8-12 \%$. Pawnshops are held to the same regulatory standards as traditional banks and, as publicly owned and operated institutions, are not for-profit. Accepted objects overlap significantly between the U.S. and France, but are also culturally dependent. For example, fine French wines can be pawned at the Credit Municipal, whereas this would be a highly unusual item to pawn in the U.S., acceptance of which would fall under the store owner's discretion.

Elsewhere, such as Brazil, pawnshops, which have interest rates around $20 \%$ APR, have become a more financially sound alternative for credit than traditional banks and credit cards, which charge up to $100 \%$ and $240 \%$ APR, respectively (Horch 2014). Thus, pawnshops have now caught on with the Brazilian middle class and are not seen primarily as alternative banking institutions for the working poor and immigrants, which is the case in both the U.S. and France. Further, as with France, pawnshops in Brazil are regulated nationally with strict oversight (Horch 2014).

Ar-Rahnu, or Islamic pawn brokering, provides yet another model. According to Hisham et al. (2013), because interest is prohibited in Islamic countries, such as Malaysia, pawnshops may charge minimal "safe keeping" fees rather than interest. These fees generally total less than $1 \%$ of the monetary value of an item. Further, customers may receive up to $80 \%$ of the value of the pledged item, significantly more than the $50 \%$ standard that is common in the U.S. and France. Thus, we can see how the institutional model of the pawnshop - and the notion of financial risk itself - are culturally contingent, in addition to the values assigned to accepted items.
} 
We should be weary of drawing too large a distinction between mainstream and "fringe" credit models, however, as both operate under similar logics of risk. That is to say that both mainstream banks and pawnshops fold the management of risk into their profit-model. Whereas credit card companies and banks made risk profitable in the mid-twentieth century by making risk "knowable" through metrics like credit scores (Marron 2009; Cohen 2003), pawnshops use collateral to mitigate financial risk to the business, while profiting off of exorbitant interest rates "justified" by not using credit scores and generally courting customers who may not qualify for more mainstream forms of consumer credit (Carruthers and Ariovich 2010). That said, pawnshops still make informal distinctions among customers, extending benefits such as larger loans or a longer window of opportunity to recover an object to "good" customers, meaning those who pawn regularly and generally pay interest on time (Degenshein 2016). ${ }^{6}$

To date, the existing literature on pawnshops has largely focused on either the particular economic burdens of pawn-based loans (see Caskey 1991, 1994, and Karger 2005; McCants 2007) or the socio-historical significance of pawnshops in the realm of consumer credit (see Tebbutt 1983; Woloson 2007, 2012; McCants 2007). Few empirical studies, in particular, have much to say on the topic of how the personal objects - and their corresponding values - that anchor pawn-based loans affect the financial transaction. Behavioral economists, such as Carter and Skiba (2012), have begun to take this up, providing intriguing evidence to suggest that objects with "sentimental value" [including "wedding rings, class rings, engagement rings, and 'mother's' rings" (pp. 205-206)] are more likely to be retrieved than non-sentimental objects (such as tools and electronics, but also other kinds of jewelry), leading the authors to conclude that customers "avoid making big financial mistakes when using pawnshops" (p. 200) due to sentimental attachments that do not exist with unsecured loans. Yet their research design is problematic in several ways. First, the authors impose their own ideas of "sentimentality" onto a somewhat arbitrary subset of objects without knowing how the customers themselves may have felt towards the objects [also ignoring the oft-critical "use-value" a person may derive from a particular object, as illustrated in Stallybrass (2001)]. Second, there may be differences in the financial resources of people who own - and pawn - wedding and engagement rings versus those who do not, which the study design cannot capture (pawnshops do not collect financial data on their customers). Third, the authors ignore one of the fundamental features of pawnshops, which is a lack of credit reporting. This is important because in a pawnshop where the interest is $20 \%$ per month and the principal is half the market value of the object, a customer will have paid the market value in full in interest alone after 10 months and must still repay the principal in full to retrieve the object. It is therefore wrong to think of defaulting as a "financial mistake" in this context; on the contrary, defaulting may be in the best financial interest of a customer after a number of months, although not necessarily in the best sentimental/emotional interest. Knowing exactly which kinds of value (economic, sentimental, functional, or otherwise) are the "real" or "true" motivating values for any given pawn, and at any given time over the course of the loan, is therefore unreasonable. For this reason, economic models governed by predictable or

\footnotetext{
${ }^{6}$ See also, Anya Degenshein, "What's lost in the 'fringe': the economic and social processes of an urban pawnshop" (MA thesis, Northwestern University, 2014).
} 
stable behavioral assumptions or transactional costs will at best provide a shallow or partial understanding of why customers do or do not retrieve their objects, and at other times the models will lead to completely inaccurate conclusions.

Understanding better how an object is valued in a given transactional momentor "valuation event" (Mennicken and Power 2015) — however, is both an achievable and worthy endeavor. The social construction of personal and market values has long been of interest to sociologists (see, for example, Marx 2001; Weber 1964, 2001; Simmel 1971, 2004), but has gained tremendous traction over the past thirty years as an area of inquiry. In his study of auctions, for example, Smith (1989) shows how auctions resolve the problem of ambiguity in market price through social interaction, when individuals simply do not know the precise value of certain things. Relatedly, Zelizer's (1985) Pricing the Priceless Child demonstrates the dynamic and interconnected nature of market price and personal value and the ways in which social actors directly impact these valuation claims and assessments. Zelizer casts her analytic eye on the valuative shift that occurred in the early twentieth century during which children went from being viewed as monetary assets and contributors to household incomes to being understood as sentimental and "priceless" family objects that the market could only continue to value based on this cultural reasoning. Doing so, Zelizer demonstrates how the market deals with "those aspects of society that are regulated by sentiment and value" rather than price (1985, p. 15), and how cultural, extra-economic value can impact market price.

Less explored is the way that competing schemas of value come together to create price. In their edited volume on valuation and pricing, Aspers and Beckert (2011) point out that "value and prices differ but markets establish economic value in the form of prices, both as a result of coming together to trade and as an outcome of a specific institutional structure (p. 27). Economic value still cannot be reduced to market price, however, as the amount someone is willing to pay or sell an object for may be different than the object's market worth $(2011$, p. 27). This is especially true in the pawnshop, where customers are flatly told they will receive about half of the market value of an item. In his work on the price mechanism for contemporary art markets in New York and Amsterdam, Velthuis (2003) highlights the symbolic dimensions of price, noting its connection to quality, reputation, and status (p. 184; see also Mears 2011). Connecting the price mechanism to earlier work on the social construction of value, Velthuis importantly finds that prices themselves can help construct value in the art world, and the value may not be tied to just the art object itself, but also the people involved in the exchange. But the social value of an artist or art dealer is not always positively correlated with price; Fine's (2003) research on folk art shows how the absence of social capital of a folk artist generally increases the value - and price - of that artist's work. Fine's work foreshadows some of my own findings, but where my findings differ is that the values used to negotiate prices in a given pawnshop transaction do not necessarily have any effect on the market value of the item, highlighting the multiple salient values and prices an object may have within the same site. My work uncovers which types of values are salient in a pawnshop and how they are rhetorically deployed, even when they clash with known market values.

My understanding of the importance of social relationships in pawnshop transactions is very much indebted to, yet also distinct from, the social relations approach to economic transactions. First developed by Zelizer (2005), the social relations approach 
offers a new way to understand the intermingling of the economic and the deeply personal. The approach consists of "a minimum of shared meanings, operating rules, and boundaries separating one relation from another" (2005, p. 33). It helps explain, for example, how sexual intimacy can in one social context be seen as priceless and in another have clear monetary values (Zelizer 2005), or how the amount of money a person is willing to pay for something marks them as "differently situated" (Wherry 2008, p. 363). Fleshing out Zelizer's concept, Bandelj (2012) adds that relational work emphasizes the need to know "what kinds of symbols, practices, and media of exchange is appropriate for different kinds of relationships" (p. 176). Importantly for my own work, Bendelj highlights the "work" involved in such relationships and also how negotiation provides the opportunity both to reveal social inequalities and (temporarily) to overcome them, such as using social disadvantage to increase the amount of money a customer receives for an item. Yet focusing on the rhetorical work over the relational work emphasizes that little is known about the "true" or actual relationship behind the transaction and also that what is said is more important thanand not necessarily reflective of - the actual relations. Moreover, my focus on the discursive better enables me to pinpoint a specific mechanism behind price production, while also stressing the highly temporal nature of a negotiation, an event that may or may not be reproducible.

Shared meanings are central to the discursive strategies of valuation in the pawnshop. After all, the strategies only work if they tap into meaning that both parties agree can and should change the price of the object given the institutional context. Thus, when I speak of objects in the pawnshop as cultural objects, I invoke Griswold's (1987, p. 4) idea of "shared significance embodied in form [...], an expression of social meanings that is tangible or can be put into words." The shared meanings revealed in the relative effectiveness of the discursive strategies, then, demonstrate how meanings assigned to objects are not assigned unidirectionally, from externalsuch as market or "expert"-forces, but rather are a product of what Halle (1993, p. 55) terms "social forces." Further, these meanings depend upon interaction with both the object in pawn and the other actor(s) involved in the negotiation of value, who must be socialized to understand the basic premise of the negotiation process (Simmel 1971; Goffman 1967). In this sense, the social process of negotiation of value has a strategic, perfomative aspect, reliant upon both the individual performance choices of the actors involved as well as successful reception of the performances by the actors involved (Alexander 2004; Goffman 1967). In other words, the valuation process itself can be understood as a performance of culture (Berezin 2002), informed by a cultural object, and carried out with specific ends in mind.

Finally, the concept of discursive strategies traces its roots to Foucault (1990), who was adamant in his understanding of discourse as both a strategy of power and resistance. He writes, "discourses are tactical elements or blocks operating in the field of force relations" (Foucault 1990, pp. 101-102). For Foucault, discourses are constrained by social and institutional context, but create room for change in the standard or anticipated arrangement of social relations and relations of power at play in any given interaction. Thus, I use the word "discourse" rather than, say, "description," to imply the importance of social contexts and relations. Again, this is intimately connected to relational approach, but in the context of the pawnshop, where assumptions about social relations often occur yet little is actually known about the people 
involved in a given transaction, the emphasis on discourse over relations is useful. This is even more relevant given my interest in the mechanisms of price setting, rather than the larger relational context. Moreover, while some of the strategies of valuation are narrative in nature, most instances I observed did not draw upon stories with characters, sequencing of events, or overarching narrative structures (Ewick and Silbey 2003, p. 1341), therefore discursive strategies of valuation make more sense than valuation or valuative narratives. The speech tactics may be thought of what as what Ewick and Silbey (2003) call "everyday forms of resistance" though. The lack of specific, regulated procedure as well as the violation of the broader principles of who and what determines market prices, allow the discursive strategies to act as an everyday form of resistance to a mainstream banking sector and financial industry that benefits a privileged few.

\section{Studying Second City Pawn}

The data in this article come from thirteen months of ethnographic research at Second City Pawn, a pawnshop located in a racially and ethnically diverse neighborhood on the North Side of Chicago. ${ }^{7}$ From the spring of 2013 to the spring of 2014, I spent from two to eight hours per week in the field, jotting down notes while in the shop. The notes were subsequently typed into a full set of field notes and coded numerous times, both with and without the assistance of Atlas TI. I was able to observe all aspects of the pawnshop, from anywhere, although this usually meant from a small watch-repair station tucked into the corner of the showroom floor, from where I could both hear and see the most. I asked the employees questions as they arose, generally when customers were not in the store or when I was in the back office, where customers were not allowed; however, no formal, recorded interviews were conducted.

During the thirteen months I studied Second City Pawn, there were five primary employees who worked at the shop in various groups of three-one manager (or assistant manager) and two general employees, or sales associates - on any given day, with some employees logging more hours than others. These five individuals remained near constant throughout the study, with one sales associate gradually phased out and eventually replaced by a new employee during my last few months of study. My rapport with the employees was strong enough that they frequently invited me to socialize with them as a group outside of the shop, and on a couple of occasions I did. I interacted with customers in the shop regularly as well, although this was usually limited to exchanging pleasantries, as I generally preferred to observe customer-employee interactions. ${ }^{8}$

\footnotetext{
${ }^{7}$ For more information on the shop's layout, customer demographics, and the employees who work at the shop, see Degenshein (2016) and Degenshein "What's lost in the 'fringe."

${ }^{8}$ I also conducted three pilot, tape-recorded, semi-structured, open-ended interviews with "regular" customers (e.g., customers who came into the shop at least several times a month to pawn an item or make an interest payment on an item in pawn). It quickly became clear, however, that customers were not fully forthcoming about the extent to which they relied upon the shop, misrepresenting what I subsequently observed and discovered from conversations with employees. Since personal finances are a delicate subject matter, it seemed that observation would be the most powerful — albeit limited — way to learn about customer use of pawn-based loans.
} 
The owner of the shop, Joey, owns (or co-owns with family members) several independent (e.g., non-publicly traded) pawnshops in and around Chicago, and several more pawnshops and other alternative lending businesses in at least two other states. ${ }^{9}$ His familiarity with pawnshops and other alternative lending businesses is therefore significant. But it also suggests that any risk he was taking by letting me study his shop was likely perceived as minimal, given both that I would obscure identities and locations and also that his assets are substantial and his position as a business owner well-entrenched.

The shop itself is comparable to the average in Illinois. Table 1 compares some of the annual shop statistics to the averaged licensed Illinois shop. I was unable to obtain information on the profit of this business since it is not a publicly traded company, but I was able to obtain data on the annual amounts financed for the time period I was there at the request of the owner. ${ }^{10}$ Further, there are plenty of repeat customers, customers that come in one or more times per week. Staff often pointed out such customers to me and there were from five to ten customers I saw multiple times during my study. Nonetheless, repeat customers were still a minority of the people I saw. My suspicion is that pawning customers tend to be repeat players (they have to come in multiple times usually, even if for just one item) but many folks come in to the shop to buy or sell as a one-off and the staff did not know these customers. However, even the customers they did "know," the staff only knew partial stories, whatever the customer wanted to reveal about him or herself.

Table 1 compares averaged pawning data from Second City Pawn for the period October 22, 2011 - October 22, 2013 to averages of all registered pawnshops in Illinois for the 2012 and 2013 calendar years (total number of licensed shops reporting is 298.5 for the two-year period). Second City averages were calculated using data supplied by the shop's owner upon request. Data for Illinois State averages were calculated using the Annual Statewide Disclosure Report Results, collected by the Illinois Department of Financial and Professional Regulation (2012); IL State data can be accessed at http://www.idfpr.com/Banks/CBT/PAWNBROK/pawnrept.asp

The method of ethnography enabled me to focus on the how (Riles 2011) of valuation processes. It is an underutilized method in sociological studies that investigate the banking sector, where interviews, case study, and archival analysis, as well as statistical methods, still dominate the area of inquiry. However, ethnography enabled me to "follow the meanings" (Appadurai 1986, p. 5) of objects in social interaction much more closely and directly than another method would have allowed. Before starting fieldwork, I immersed myself in much of the existing literature on pawnshops and fringe banking. I therefore came to Second City Pawn motivated by certain kinds of questions and theories I was interested in studying, although the discursive strategies used to negotiate price were not among these. I only became interested in this topic after reviewing my field notes and noticing patterns in the data.

\footnotetext{
${ }^{9}$ Accumulation of pawnshops and other alternative banking businesses, such as payday loan shops, appeared to be an ongoing process for Joey, who was in the middle of a new purchase when I began my time at the shop.

${ }^{10}$ I do not have longitudinal data for the shop and consistent data for the state of Illinois only dates back to 2006. What we can tell from that, though, is that the number of licensed shops reporting grew nearly $50 \%$ from 2006 to 2013 in the state of Illinois, and also that the average dollar amount financed per licensed shop increased by over $165 \%$ in these seven years, perhaps propelled in part by the recession.
} 
Table 1 Summary Statistics, Second City Pawn and Illinois State, 2012-2013

\begin{tabular}{lll}
\hline & Second City Pawn & IL State Average \\
\hline Total Dollar Amount Financed & $\$ 1,107,154.37$ & $\$ 1130,908.37$ \\
Total Number of Pawns & 7129 & 7851 \\
Mean Loan Amount & $\$ 161.13$ & $\$ 144.14$ \\
Monthly Interest and Fees & $20 \%^{\mathrm{a}}$ & $17.64 \%$ \\
Default Rate & $27.9 \%$ & N/A \\
\hline
\end{tabular}

${ }^{a}$ Loans over $\$ 300$ have a $10 \%$ monthly interest and fee rate at Second City, but I do not have data on the weighted percentage of loans above and below $\$ 300$. Since the mean loan is $\$ 161.13$, and the median likely to be substantially lower, most customers pay $20 \%$ monthly interest

For this reason, I did not record every instance when a discursive strategy of valuation was employed while I was in the field. Still, this kind of valuative strategy was so commonplace that I would expect to hear at least one - if not all three - used on any given day of observation. The instances I recorded, then, and the examples offered here, are generally longer, more revealing, or more explicit; but I do not consider any of the three kinds of discursive strategies of valuation exceptional and would expect other researchers observing the shop to hear the same strategies in play.

Finally, the findings of ethnographic work cannot be generalized to broader populations, even within the same geographic area, but the social processes we observe in any given site may help to illuminate discoveries in other settings. Thus, this study does not claim to represent the exact process of valuation, or the specific social relations, in all pawnshops in the United States, in Illinois, or even in Chicago alone. I would expect, however, for the theories developed here about valuation strategies to be informative for future studies of pawnshops, the fringe economy, and the financial sector more broadly.

\section{A typology of discursive strategies of valuation}

“How much are you lookin' for?"

This question initiated the majority of transactions in which a customer sought to sell or to pawn an item to the store. The question also places the onus of knowing the value of an item on the customer, who may be unaware of its current market worth. The initial response was therefore generally just the start of a negotiation process, as customers most often overestimated the amount of money they would receive for a particular object, or simply wanted - or needed - more money than the first counter offer made by the employees.

The base calculation of an object's market worth was straightforward enough for employees. Early into the study, Marc, a gregarious employee of Puerto Rican descent who was the store's best salesperson, explained the process to me. He said that when a customer brought in an item whose value he was not certain of due to previous transactions, he would use his smartphone or the store's tablet computer to check both the retail price of the item sold new, as well as the price the item had been sold for used, usually found on eBay or Craigslist. The initial amount of money offered for a 
customer looking to either sell or pawn an item would generally be $40-50 \%$ of the amount the item had been sold for used on eBay. ${ }^{11}$

For jewelry, this process was a bit more straightforward. Bobbi, the white, dreadlocked, no-nonsense store manger, explained to me that the amount offered on gold and silver jewelry was directly tied to the market price for the metal at the time of transaction. Jewelry was therefore first tested to ensure the metal was real silver or gold (and what karat, if gold), then weighed in pennyweights. Gemstones would be evaluated by the clarity, quality, and size of the stone(s) and extra value would then be added accordingly. Customers were generally offered a little more than half the market value for jewelry because it had the most universal and regulated market value and could always be sold as scrap metal, which the store frequently did for items sold to the store directly or defaulted on. Moreover, it was store policy to offer slightly higher loan amounts (e.g., anywhere from 50 to $75 \%$ of the used market value) to "good" customers when requested, or to those customers who pawned frequently and rarely defaulted. ${ }^{12}$

Employees were surprisingly transparent about this portion of the valuation process, often telling customers what the going rate on eBay was and explaining that in order for the store to turn a profit, or in reality, for the store to make as high a profit margin as the owner desired, the shop could only offer about half the going market rate for objects that customers wished to sell or pawn. Often the employees would even explicitly tell customers they could likely get significantly more if they sold it themselves on eBay or Craigslist; however, most customers appeared to prefer immediate access to cash, or perhaps to bypass the time, effort, and resources (such as reliable and regular Internet access) it would take to sell an item online.

Assigning a market value, in the form of a dollar amount (or price), was one of the initial responsibilities employees had when customers brought objects into the store. In practice, it was the process of turning personal objects embedded with numerous kinds of value into objects with one overriding value, namely price. Whether the item was a television, a saxophone, or a ring, employees were charged with stripping away highly personal value(s) an item may have gained under the owner's possession, and assigning a final dollar amount for a loan or direct exchange.

The pawnshop is striking for how visible it makes the process, including the informal rules of engagement that are involved in negotiation. The store never insisted on the process of price negotiation (or "haggling"), of course, and it was unnecessary if the dollar amount the customer was seeking matched or fell below the store's baseline value-assessment. But pawnshops are one of the few formal contexts in the United States where price negotiation is acceptable. Employees therefore expected some price negotiation and most customers did as well,

\footnotetext{
${ }^{11}$ This 40-50\% markdown off the market value as a means to determine the loan amount seems rather universal, both elsewhere in Chicago and across the United States. For example, I visited three other pawnshops in Chicago, both independent and publically traded businesses, and found this to be the norm. Furthermore, in his 1994 book Fringe Banking, economist John Caskey also found that pawnshops across the country used "about a 50\% loan to collateral ratio" (p. 42). This is much more money than the fees eBay charges for sellers using their platform. According to eBay's website, eBay takes $10 \%$ of the sale amount, up to $\$ 750$. Listings may also incur small fees ranging from $\$ .10$ to $\$ 6$ for optional listing "upgrades." See eBay (2016).

${ }^{12}$ For more on what constitutes a "good" financial actor in the context of the pawnshop, see also Degenshein (2016) and Degenshein "What's lost in the "fringe."”
} 
although informal rules of negotiation still had to be adhered to. For example, customers who did not want to engage in the process of price negotiation but still expected to have a beneficial outcome violated the informal social rules - and business practices - of the shop. These deals were generally met with resistance from employees. One employee, Li, an Asian American in his early twenties with an outgoing and competitive personality, expressed his frustration with such situations to me:

Li: Some people come in and just expect a discount, without bargaining or haggling.

AD: So what do you do?

Li: I'm like, “That's the price." And they say, "You can't do better?" And I'm like, "What's your offer?" You [the seller] always want to be in control.

If the customer still refused to engage in the haggling process, not budging on her requested or offered price, $\mathrm{Li}$ would simply walk away from the deal. The employees did not seem to care if a customer's continued unwillingness to partake in the process was due to ignorance of the process or strategy. Employees were not interested in parsing out these details or teaching the customers proper negotiating decorum; instead, they interpreted the behavior as rude or improper, shutting down the deal by saying, "I'm sorry, that just won't be for us," or "Sorry, that's the price." Thus, while there was no formal policy on haggling, it constituted an informal rule of the store that could not be transgressed or bypassed if a customer was unhappy with the store's pricing of an object. The inability or unwillingness to play by these rules, though, had real consequences, effectively acting as a barrier to access.

Customers and employees who did engage in the process of negotiation relied on strikingly similar discursive strategies to further their end of the bargain. Regardless of the outcome, my field notes revealed three commonly reoccurring rhetorical strategies used in negotiations to validate one's suggested price. These strategies appeared repeatedly in my field notes over the entire 13 months, independent of the employee involved and of whether the customer was a regular who came in every week or a firsttimer to the shop. They included: reference to the specific material attributes of an object, reference to the unique biographical history of an object, and reference to financial need and (relative) social positioning of the customer. These strategies were certainly not discrete and it was not uncommon to hear more than one being used in a transaction. However, since the strategy could stand on its own, I treat them as distinct analytic categories.

\section{Specific material attributes}

Employees and customers often referenced a physical characteristic of an object in negotiation that could not be observed, at least not with an untrained eye, and therefore required explicit articulation. This frequently involved stating where the item was made or who made it, or perhaps what the particular material components of the item were. For example, one Friday afternoon at the start of the long Memorial Day weekend, a Black man who appeared to be in his fifties, wearing a baseball cap and a polo tee shirt, came 
into the store carrying an electric bass guitar and small amp. The man immediately placed the items on the main counter in the middle of the store and said to Marc, who was standing behind the counter, "I want to pawn this, I need some holiday cash." The customer, who was not greeted by name or a knowing "Hello!" by Marc, was likely new to the shop. Marc asked how much the customer was looking to get; the customer replied lightheartedly, "A buck and a half!" and then began talking about what a "good instrument" the bass was, referring to both the guitar and the amp as "my babies."

Marc asked to see the bass, far from the first bass guitar that had come through the store; he looked at the back of the instrument and pointed out that the guitar was made in China. Marc then walked over to the store's western wall, which was lined with guitars and basses for sale, and pulled down a couple that looked identical to the customer's. Marc checked the back of the instruments as he had just done with the customer's, stating one was from Indonesia and the other was Korean made, although they were all from the same company. In a straightforward but polite manner, Marc then told the customer that the Chinese model had the lowest value of all the basses made by that company, with American-made models fetching the highest prices and the Korean and Indonesian models in the mid-to-low end of the value spectrum. Marc then quoted the customer $\$ 70$ for both the amp and bass. Clearly disappointed by the number but not angered, the customer responded, "You can't do anymore?" explaining that the amp was "a nice amp." Marc agreed that the amp was nice, but said he still could not offer more than half the market value for used items. Upping the offer slightly, Marc then said, "I can do $\$ 75$, but not any higher than that." The customer accepted.

This exchange is notable for its explicit references to the object's material attributes, which in turn affect the market value of the item. Marc explained to the customer that his particular model was worth less than an otherwise seemingly identical model fabricated in a different country. The assertion could easily be backed up by an eBay search revealing the various prices of the guitars, but Marc did not even have to do that, as the valuing schema he relayed made intrinsic sense to the customer. Particularly in this US context, Chinese-made items are understood to be "cheaper" or inauthentic versions of better items, even when crafted from the same exact materials as their superior counterparts. The customer still succeeded in negotiating the price up a few more dollars, though, calling attention to the quality of the amplifier after the bass has been written off as having little value; neither man mentioned the material origins of the amp, but presumably the brand itself was notable, even if it did not otherwise appear special to my untrained eye).

If being "made in China" commonly signifies a reduction in value in the United States, being "custom made" often signifies the reverse. For example, one spring afternoon, a middle-aged white man came into the store looking to pawn several pieces of jewelry. Li, who was working the showroom floor, instructed the man to go into one of the booths in the back corner of the store to have his jewelry assessed. The booths were where all monetary and jewelry transactions took place, separating the customers from the store's cash reserves and back office with eight- inch-thick bullet proof glass teller windows. They also offered some privacy from the showroom floor. The customer entered one of the booths and passed a couple pair of earrings and a ring under the glass through to Miguel, the assistant manager and a Mexican-American who often had soccer matches streaming from his laptop in the back office. Before Miguel even had a chance to test the metals, the customer noted, as though to preempt any unfavorable assessment of worth, "The two iridescent earrings are custom made by a jeweler." 
But even "custom" is constrained by common market values. After a minute or so of examining the jewelry, Miguel told the customer, "Unfortunately these are costume jewelry, so it wouldn't be for us." In a last ditch effort, the customer assured Miguel that he would return for the "special" items, so therefore couldn't Miguel offer something for them. Miguel repeated himself, stating once again that the items were costume jewelry, adding that the ring was real silver, but worth less than five dollars, and $\$ 5$ was the minimum loan amount the shop extended. "Sorry about that, sir," Miguel said, turning back to his desk as the customer collected the items, accepting the rejection without further protest.

Here again, the specific material attributes of an item were highlighted as part of the discursive bargaining strategy, in this case both to increase market value ("custom") and to decrease it ("costume"). The word custom was intended to connote pricelessness, while also suggesting that the items required a particular social capital to appreciate that could not simply be seen - it had to be told. Whether or not the pieces were in fact custom, that attribute did not override the value of the materials from which they were constructed in the end. Miguel's assertion that the pieces were costume jewelry is the culturally specific, and perhaps also polite, way of saying jewelry is "fake" or not made from precious metal.

In both examples we see how the materiality and construction of the objects were articulated and used to debate the market values by both customers and employees. A Chinese bass lost value, a "nice" amplifier gained value, and custom-costume jewelry had no value to the store at all. How adjectives such as "nice" translate into precise price modifications remains somewhat opaque, but it is clear that they operate within bounded limits for any given item. In addition, some descriptors, such as "costume," cannot be overridden.

\section{Unique biographical history}

Rather than drawing upon the specific materials or means of construction that went into the fabrication of an object, some customers referred to the history of an item, or the object's particular biography, in an effort to increase its value. Just as people have biographies, so, too, do objects (Thomas 1991; Kopytoff 1986), and features of invisible biographies could be put into play as an indicator of value. Here, value was purportedly captured in the treatment of an object or the experiences associated with it. Such was the case for a white, middle-aged man who came into the store one afternoon carrying what he described as a "studio amp," looking to sell the item to the store. As Li began to inspect the amp, he asked how much the customer was looking to get for it. Rather than responding forthright with a number, the customer launched into a biographical history of the object, explaining how he bought the amp a number of years back for $\$ 1100$, still the current retail value he said, but that because it was used solely as a studio amp and not toted around to gigs, it had "years on it, but not miles." This meant that the amp was in excellent working condition, worth more than a similar used amp. Further, the customer explained how he had replaced the "tubes," leaving the amp in better condition than its years would suggest, an added reference to material condition. The customer finally said he was looking for $\$ 650$.

Li looked the item up on eBay, and responded that the amp was only selling for $\$ 350-\$ 400$ used, and that therefore he could not give $\$ 650$. As a counter-offer, Li 
suggested $\$ 200$. Seemingly shocked by such a low offer, the customer once more launched into a defense of the object's history, explaining that its pristine condition could not be compared to just any similar model on eBay. The customer added that he did not even wish to sell the amp, but that he had nerve damage in his fingers and therefore could no longer play the bass, which meant he had little use for an amp. Unmoved by the story, Li held firm at $\$ 200$. The customer said there was "no way" he could part with the amp for such a low price, certain that it was worth more, and left the store, exasperated by the encounter.

Once again, the discursive strategy relied upon conveying unseen value, bounded by the external market and the institutional context. The strategy was unsuccessful in this case, the customer's and the store's perceived values ultimately incommensurable, or "incomparable" (Espeland and Stevens 1998), likely because the gap in perceived market worth was so great. Yet this kind of tactic was deployed by a variety of customers, sometimes successfully. As with this case, customers would often reference the way electronics were used or stored when trying to increase the assigned monetary value of an object being pawned or sold to the shop. Object biographies may also include how an object was acquired and its movement through time and space (Thomas 1991). In the case of fine jewelry, it was not unusual to hear customers talk of an item's vintage or heirloom status as deserving of additional monetary value, on top of the value of the raw materials involved.

Much like materiality, however, explaining or highlighting an object's history could decrease market value, too. For example, the sight of scuffs, marks, discoloration, or foreign smells or substances on objects suggested poor or improper treatment and use to employees, who generally avoided taking in objects with known - or presumeddefects. The "correct" use of an object mattered, although once again, within bounded limits if the object was generally functional. Disagreement over the valuation of objects did frequently concern the extent to which the history of the object mattered or exactly how much a good, or improper, history was worth in dollars. Further, since there were always multiple classification systems at play, such as the going price on eBay versus what a customer himself paid for an item or the money he (supposedly) spent on maintaining and improving it, the extent to which the biographies mattered was always mediated by other factors (Kopytoff 1986).

\section{Financial need and social positioning}

The most common discursive strategy of valuation deployed by customers, however, had little to do with the object itself. Instead, it drew upon the customer's own biography or social positioning. Customers regularly referenced their precarious socio-economic positioning to increase the monetary offer on an object. It happened so often, in fact, that before long I did not track each instance in my field notes, only the more exceptional interactions. For any given two-three hour period I was in the field, I would expect to hear this strategy used at least once during my observations, assuming foot traffic into the store was steady. The relative financial need was being valued as part of the object's market worth, pointing to the ways in which object values and personal biographies become intertwined (Fine 2003; Stallybrass 2001; Belk 1988), but here, in a rather unexpected way.

For example, one cold evening in late January, a tall Black woman, likely in her late thirties, bundled in a dark puffer coat, came into the shop with a cordless microphone 
and transmitter. A musician himself, Marc, who worked more hours than any other employee and was at the shop that evening, struck up a conversation with the woman about music performance. The customer shared that she sang at Chicago-area hotels some evenings to make money. After coaxing the woman into singing several bars of music, Marc inspected the items and began telling the woman that the frequency her mic ran on was not going to be any good soon because cell phones were going to take it over. He offered her a \$200 loan. The woman protested, saying, "You can't do a bit more? They're not going to change the frequency over the course of the next month before I come to pick it up!" A beat of silence passed, and perhaps sensing that debating the physical attributes of the object may not be a winning strategy, she added more solemnly, "I just need a bridge until tax time." Marc reconsidered briefly and then offered her $\$ 250$, a substantial increase.

In this interaction, the woman appealed to both the logic of the speed of technological change, and, sensing that it would not be enough, made a moral appeal to survival, money to get her through the end of the month when tax rebates would start being issued. The customer also made clear that the objects were of vocational value to her, things she used to make money; they were part of her own biography, she was dependent upon them for financial support. Other customers made similar appeals, sometimes referencing a recent layoff or need to pay a bill. Still others would cite an exact need, such as gasoline for a car or copay on a necessary medication. Counter intuitively, personal information that suggested a weakened or subordinate position of power was used as a strategy to strengthen a customer's relative position in the bargaining process. Put differently, during such negotiations, a lower socioeconomic status was a weapon of the weak that foregrounded the weakness itself.

Reference to social position and power was sometimes even more explicit. For example, one evening a Latino man and women, who looked to be in their late forties, entered the shop, greeting Marc in Spanish, the greeting signaling a preference for communication in Spanish. The man and woman, who appeared to be a couple due to their close physical proximity and rapport with each other, asked to see various pieces of gold jewelry in the store's jewelry cases, inquiring, for each piece, the price and number of karats. At one point the couple seemed to settle on a couple of pieces, a chain and a pendant, which Marc told them were priced together at \$740. Giving it some thought, the man asked for a final price of $\$ 640$. Marc said he had to consult with his boss about the requested price, disappearing into the back room where Joey, the owner, was doing paperwork.

After nearly $10 \mathrm{~min}$ of conversation in the backroom, Joey and Marc finally emerged. Joey greeted the couple and asked Marc to serve as translator, which Marc did. Speaking in English clearly, evenly, and slowly so that Marc could provide an accurate translation, Joey first thanked the customers for their interest in the pieces and for their offer. He then explained that his gold prices were very low, "just above scrap," so his ability to bargain on the pieces was limited. Joey said that $\$ 640$ was, in fact, less than what he could get for the pieces if he sent them in as scrap and that he could therefore not part with them for such a low price. The man chimed in and, as translated by Marc, said that he and his wife were loyal customers, the woman pointing to the gold necklaces she was wearing. Again thanking them for their patronage and good taste, Joey countered with $\$ 680$. 
The couple was clearly not satisfied with the price, however, telling Joey that it was his store and if he wanted to sell for less, he could. Joey agreed, stating, "I could sell these to you for two cents," but that that would simply be bad business, which he was "sure" the customer would understand. At one point during the back and forth, the woman began to express interest in a pair of modest gold hoop earrings, which Marc took out of the case for her to inspect. She added the earrings to the pile of other items and asked for a new deal. Joey said he could do $\$ 700$ for everything, which he thought was "more than fair," stating that he would even throw in a DVD for free. Laughing a bit, the couple said they were not interested in the DVD, redrawing the boundaries of the negotiation, and asking for $\$ 690$ for the three gold items they wanted. The customer then added, "Ten dollars is nothing to you." Joey gave a small chuckle of acknowledgement, his much higher social and economic positioning as a lucrative businessowning white man exposed, used against him, suggesting that it was morally unjust to insist on the higher price when $\$ 10$ meant less to him than it did to the customers. After a moment, Joey agreed to $\$ 690$.

This encounter perfectly illustrates how negotiations inside the pawnshop are constrained by social relations that exist outside of it, yet not always in the most obvious way. The unequal power relations between the shop owner and the customers that would be expected to benefit the owner, was used against the owner in the negotiation as justification for resisting Joey's price. This discursive strategy was therefore "deployed to achieve a momentary reversal of the more probable relational outcome" (Ewick and Silbey 2003, p. 1331). "Momentary" should be emphasized here, since unlike the folk artwork in Fine's (2003) research, the discursive strategy would not ultimately affect the market worth of the jewelry outside of this one transaction. And while the negotiation of value depended on mutual understanding of socioeconomic relations outside of the store, and how they affected negotiations within it, there was no guarantee this strategy would work similarly again for this couple. Joey also never asked the couple what they did for a living or how much money they made, showing the reality of the relations to matter less than the discursive presentation in the bargaining moment.

The racial-ethnic power differential could hardly be debated, though. A white man born in the United States is understood to have more power in the United States than an immigrant couple from Latin America with dark skin and presumably limited English abilities. As follows, the rhetorical tactic used also illustrates the resistance that can occur within relations of power in unexpected ways, providing another example of the multidirectional flow of power (Foucault 1990). In such transactions, increased economic value is derived from lower social positioning, forming what Appadurai (1986) calls a regime of value, or assumptions about an object's worth that are mutually constitutive of the social relations the object exists within. Conflict over the correct regime will always emerge, as "not all parties share the same interests in any specific regime of value" (Appadurai 1986, p. 57). It is not always clear which regime of value will prevail in any given transaction, but they are rooted in cultural assumptions and relations of power that have the ability to flow through commodities, transcending the localized systems of meanings (e.g., the market price of gold on a given day or "bad business practice") and ultimately affecting economic outcome (Appadurai 1986, p. 15) through the discursive devices used in the bargain. 


\section{Discussion}

If one thing is clear, it is that in any given transaction at Second City Pawn, numerous regimes of value were always at play. Further, with the exception of the relatively constant value-added to being a "good" customer, and the high and low boundaries that all transactions occur within, my field notes do not reveal the consistent superiority of one of these regimes, nor even the conditions under which one of these regimes will be more salient than another. Yet despite a theoretically limitless number of regimes of value to call forth, my data reveal that three specific discursive strategies of valuation were repeatedly deployed in negotiations over object value. These included reference to specific material origins of an object, reference to object biographies that reveal use, and reference to the customer's financial need or social position as a kind of moral appeal or illustration of what a given amount of money means to a particular person depending on her social standing.

The discursive strategies of valuation themselves provide further support for understanding the relationship between market price and noneconomic values as dynamic and co-constitutive (Zelizer 1985, 1994; Wherry 2008; Baudrillard 1988). Yet while the relational model excels at capturing how value changes over time, born of social relations with competing - and dynamic - interests and goals, my work highlights a key valuative mechanism in the formation of price, namely discursive strategies. These rhetorical strategies put certain forms of value, often invisible, into direct play in a given transactional process. Discursive strategies tap into shared cultural assumptions as well as structural realities, although they do not reflect the totality of a given transactional relationship, or even necessarily the reality of the relationship-who the people involved are remains largely obscured. The strategies tap into these shared understandings nonetheless, with the objective of at least temporarily changing an object's price. My data also plainly show that multiple valuative schemas are at play within any transactional event and that predicting which schema will be used or when it will be successful is difficult. Social relations inform transactions but do not determine them.

Discursive strategies are not limitless in their ability to affect change, of course. They exist within very real, if socially constructed, constraints of the market, as well as both formal and informal business constraints that limit the effectiveness of certain strategies. The discursive strategies are also bound to their cultural legibility. As Griswold (1987) points out, interpretation of correct, shared cultural meaning(s) is a key component of "market success" (1987b, p. 11). The context of the exchange is likewise crucial to its interpretation (Thomas 1991; Wherry and Crosby 2011; Wherry 2008, 2012; Zelizer 2005). In other words, values - both personal and market - are socially constructed and have no absolute basis, and therefore values are never "a 'quality' of objects, but a judgment upon them which remains inherent to the subject" (Simmel 1971, p. 63; see also Halle 1993). But price is not the externally dictated, objective, impersonal value we often assume it to be. Within limits, there is room for individuals to construct and negotiate price using noneconomic, culturally-informed, discursive reasoning that can illuminate otherwise hidden sources of value.

One might reasonably ask if the role of discursive strategies of valuation is highly prescriptive, restrained to the somewhat idiosyncratic setting of a pawnshop, with little import to the "mainstream" financial institutions that continue to dominate the banking 
sector in both overall influence and individual use. I have evidence to suggest that these noneconomic discursive strategies of valuation are at play in the more uniformly and strictly regulated mainstream economy, too. For example, interested in the links between the pawnshop and mainstream economies, I asked Joey if his pawnshops received financing from mainstream banks. He told me that fringe banking outfits are largely discriminated against by mainstream banks, which have both formal and informal policies prohibiting the extension of loans to such businesses. ${ }^{13}$ However, Joey told me that he did receive bank financing for a number of his pawnshops, crediting his personal financial biography with his success at securing such loans. He explained that through the relationships he has cultivated with banks from his own personal needs, including paying off "a couple" of mortgages, he proved himself as a trustworthy and low- risk investment for the bank, despite his line of business.

Joey's answer to my inquiry demonstrates how referencing his own personal record of fiscal responsibility and how this should reflect upon him as a businessman was an effective speech tactic used in securing a mainstream bank loan. Drawing attention to his ties in the neighborhood and his borrowing record, Joey negotiated his social position from an owner of a "high risk" business to a trustworthy and accountable actor in need of financial assistance. In doing so, he negotiated - and changed - the value of his business in the eyes of the bank, which in turn extended him monetary loans he would not have otherwise received. This parallels quite nicely the low-to-high status move customers in the pawnshop make in their own rhetorical strategies. The key difference between the two is that for pawnshop customers, weakness itself is the weapon, while for Joey verbally countering his weakness by drawing attention to his financial strengths and past behavior is the weapon. Still, it illustrates how even in a financial context that is heavily reliant upon credit scores and has deeply institutionalized and regulated practices, a discursive strategy of valuation may be an effective means to negotiate the value of one's property, which in Joey's case is pawnshops themselves.

Still, lingering questions remain about the salience of discursive strategies. Such questions include how much we may attribute to the chosen discourse rather than some other factor or to whom discursive strategies are available. For example, it is impossible to discern from my research whether the productivity of certain strategies is highly dependent upon the objects themselves and their relative market value or perhaps on the individuals employing them. No outright patterns of discrimination emerge from my data, but ethnographic research is not suitable to answer questions about systematic patterns of inequality. One would need to conduct an experimental study to determine if a customer's race, gender, manner of dress, or age play a key role in the success of discursive strategies, or if certain strategies are not available to certain kinds of individuals. That a significant amount of financial success seems to hinge on the successful deployment of such strategies, however, suggests that these questions are important. Further, as mentioned above, pawnshops disproportionately serve people of color and lower income groups. For this reason, we should ask how the reliance on such strategies might further disadvantage these groups in an already financially disadvantageous banking environment. Due to the fluidity of how relative disadvantage can be used, the ability of discursive strategies to rearrange power relations, we

\footnotetext{
13 This is confirmed by interviews economist John Caskey conducted in Chicago some years ago; see Pick (1992).
} 
should also ask if the strategies afford more advantage than harm. Finally, how does one learn to deploy successful discursive strategies? Through observation? Experience? Instruction? Intuition? These are all important questions for continued study.

\section{Conclusion}

This article begins by asking how price, informed by competing schemas and processes of valuation, is determined for objects pawned, sold to, and bought from a Chicago pawnshop. To answer these questions, I turned to one mechanism of this process, namely, the rhetorical tactics, or as I conceptualize them here, discursive strategies of valuation. Further, I seek to understand how such strategies might be indicative of, or informed by, the relational, cultural, and institutional context in which they exist. I found three patterns of discursive strategies in my field notes: 1 . references to the specific material attributes of objects, 2. references to the biographies of objects, and 3 . references to the customer's social position or financial need. This last strategy is particularly illuminating, as it demonstrates the counterintuitive way in which low socio-economic status may work to expand one's financial options in the context of a pawnshop if articulated convincingly. Each of these strategies is at times effective and at times ineffective at shifting transactional value and ultimately price; more research is required to understand the conditions of success or failure, although it is clear that shifts in value and price occur within firm boundaries dictated by the market. Beyond this, by highlighting the discursive strategies themselves, I am able to see which valuative tools were productive in shifting price and how the tools were informed by, yet not tethered to, the social relations and cultural context they operate within.

Even if largely symbolic, the deployment of particular discursive strategies was essential to advancing economic negotiations in the pawnshop. But preliminary evidence suggests that similar discursive strategies may play an important role in more "mainstream" economic exchanges as well. Continuing to observe and chart the specific kinds of discourses used in various financial contexts is an important task moving forward, for doing so will illuminate the malleable relational tissue that connects value, market worth, and price, as well as the mechanisms that articulate relations into social action.

Acknowledgments This article would not have been possible without the cooperation and understanding of the owner and employees of Second City Pawn; I cannot thank them by name, but I am indebted to each of them. The article benefited from the feedback of the Editors and reviewers at Theory and Society. I also wish to thank Bruce Carruthers, Mary Pattillo, and Wendy Griswold for their insightful comments on earlier iterations of this project and article, and Mat Elmore for first bringing my attention to such a rich site for sociological inquiry.

\section{References}

Alexander, J. C. (2004). Cultural pragmatics: Social performance between ritual and strategy. Sociological Theory, 22, 527-573.

Appadurai, A. (1986). Introduction: Commodities and the politics of value. In A. Appadurai (Ed.), The social life of things: Commodities in cultural perspective (pp. 3-63). Cambridge: Cambridge University Press. 
Aspers, J., \& Beckert, P. (2011). Value in markets. In J. Beckert \& P. Aspers (Eds.), The worth of goods: Valuation and pricing in the economy (pp. 3-38). New York: Oxford University Press.

Bandelj, N. (2012). Relational work in economic sociology. Politics \& Society, 40(2), 175-201.

Baudrillard, J. (1988). Beyond use value. In M. Poster (Ed.), Jean Baudrillard: Selected writings. Palo Alto: Stanford University Press.

Baum, G. (2008). It's the louvre of pawnshops. The Los Angeles Times. http://articles.latimes.com/2008 /may/12/world/fg-auntie12. Accessed 17 Dec 2014.

Beckert, J. (2011). Where do prices come from? Sociological approaches to price formation. Socio-Economic Review, 9, 757-786.

Belk, R. W. (1988). Possessions and the extended self. The Journal of Consumer Research, 15(2), 139-168.

Berezin, M. (2002). Cultural form and political meanings: State-subsidized theater, ideology, and the language of style in fascist Italy. In L. Spillman (Ed.), Cultural sociology (pp. 245-256). Malden and Oxford: Blackwell Publishers.

Bradley, C, Burhouse, S., Gratton, H., \& Miller, R.-A. (2009). Alternative financial services: a primer. Federal Deposit Insurance Corporation. https://www.fdic.gov/bank/analytical/quarterly/2009_vol3_1 /AltFinServicesprimer.html. Accessed 30 Aug 2016.

Carruthers, B. G., \& Ariovich, L. (2010). Money and credit: A sociological approach. Cambridge: Polity.

Carter, S. P., \& Skiba, P. M. (2012). Pawnshops, behavioral economics, and self-regulation. Review of Banking \& Financial Law, 32(1), 193-220.

Caskey, J. P. (1991). Pawnbroking in America: The economics of a forgotten credit market. Journal of Money, Credit and Banking, 23(1), 85-99.

Caskey, J. P. (1994). Fringe banking: Check-cashing outlets, pawnshops, and the poor. New York: Russell Sage Foundation.

Cohen, L. (2003). A consumer's republic: The politics of mass consumption in postwar America. New York: Knopf.

Cowley, S. (2016). Payday loans' debt spiral to be curtailed. The New York Times June 2, 2016. http://www. nytimes.com/2016/06/02/business/dealbook/payday-borrowings-debt-spiral-to-be-curtailed.html?_r=0. Accessed 31 Aug 2016.

Degenshein, A. (2014). What's lost in the 'fringe': The economic and social processes of an urban pawnshop. MA thesis, Northwestern University.

Degenshein, A. (2016). The object economy: The banking 'alternative' of a Chicago-area pawnshop. The Chicago Dispatch. http://www.thechidispatch.com/. Accessed 8 Nov 2016.

eBay. (2016). Selling \& seller fees. eBay. http://pages.ebay.com/help/sell/fees.html. Accessed 31 Aug 2016.

Espeland, W. N., \& Stevens, M. L. (1998). Commensuration as a social process. Annual Review of Sociology, 24, 313-343.

Ewick, P., \& Silbey, S. (2003). Narrating social structure: Stories of resistance to legal authority. American Journal of Sociology, 108(6), 1328-1372.

FDIC. (2012). "2011 national survey of unbanked and underbanked households." Federal Deposit Insurance Corporation. https://www.fdic.gov/householdsurvey/2012_unbankedreport.pdf. Accessed on 15 Feb 2013.

FDIC. (2014). 2013 national survey of unbanked and underbanked households. Federal Deposit Insurance Corporation. https://www.fdic.gov/householdsurvey/2013report.pdf. Accessed 30 Aug 2016.

Fine, G. A. (2003). Crafting authenticity: The validation of identity in self-taught art. Theory and Society, 32(2), 153-180.

Foucault, M. (1990). The history of sexuality. New York: Vintage Books.

Foucault, M. (2010). The archeology of knowledge and the discourse on language. New York: Vintage Books.

Goffman, E. (1967). Interaction ritual essays on face-to-face behavior. Garden City: Anchor Books.

Griswold, W. (1987). A methodological framework for the sociology of culture. Sociological Methodology, $17,1-35$.

Halle, D. (1993). Inside culture: Art and class in the American home. Chicago: University of Chicago Press.

Hisham, S., Abdul Shukor, S., Ummi Salwa, A. B., \& Jusoff, K. (2013). The concept and challenges of Islamic pawn broking (ar-rahnu). Middle-East Journal of Scientific Research, 13, 98-102.

Horch, D. (2014). Brazil's middle class finds a lifeline at the pawnshop. The New York Times. http://dealbook. nytimes.com/2014/12/03/for-brazilians-pawnshops-are-the-antidote-to-soaring-interest-rates/?_r=0. Accessed 3 Dec 2014.

Illinois General Assembly. (2013). Illinois General Assembly: Illinois Compiled Statutes, Pawnbroker Regulation Act. http://www.ilga.gov/legislation/ilcs/ilcs3.asp?ActID=1188\&ChapterID=20. Accessed 17 March 2013.

Karger, H. (2005). Shortchanged: Life and debt in the fringe economy. Oakland: Berrett-Koehler Publishers. 
Kopytoff, I. (1986). The cultural biography of things: Commoditization as process. In A. Appadurai (Ed.), The social life of things : Commodities in cultural perspective (pp. 64-91). Cambridge and New York: Cambridge University Press.

Marron, D. (2009). Consumer credit in the United States: A sociological perspective from the 19th century to the present. New York: Palgrave Macmillan.

Marx, K. (2001). Capital: a critique of political economy. Vol. I, Book one, the process of production of capital. Frderick Engels (Ed). Translated from the third German edition by Samuel Moore and Edward Aveling. London: Electric Book Co.

Massey, D. S. (2007). Categorically unequal: The American stratification system. New York: Russell Sage Foundation.

McCants, A. E. C. (2007). Goods at pawn. Social Science History, 31(2), 213-238.

Mears, A. (2011). Pricing looks: Circuits of value in fashion modeling markets. In J. Beckert \& P. Aspers (Eds.), The worth of goods: Valuation and pricing in the economy (pp. 155-177). New York: Oxford University Press.

Mennicken, A., \& Power, M. (2015). Accounting and the plasticity of valuation. In A. Berthoin, M. Hutter, \& D. Stark (Eds.), Moments of valuation: Exploring sites of dissonance (pp. 205-228). Oxford: Oxford University Press.

Pick, G. (1992). The pawn experience: Will it ever be respectable? The Chicago reader. http://www. chicagoreader.com/chicago/the-pawn-experience/Content?oid=879550. Accessed 4 Dec 2014.

Riles, A. (2011). Collateral knowledge: Legal reasoning in the global financial markets. Chicago, London: University of Chicago Press.

Simmel, G. (1971). Exchange. In D. N. Levine (Ed.), On individuality and social forms: Selected writings (pp. 43-69). Chicago: University of Chicago Press.

Simmel, G. (2004). The philosophy of money. D. Frisby (Ed.) (trans: T. Bottomore and D. Frisby) from a first draft by K. Mengelberg. London and New York: Routledge.

Smith, C. W. (1989). Auctions: The social construction of value. Berkeley: University of California Press.

Stallybrass, P. (2001). Marx's coat. In D. Miller (Ed.), Consumption: Critical concepts in the social sciences. London, New York: Routledge.

Tebbutt, M. (1983). Making ends meet: Pawnbroking and working-class credit. New York: Leicester University Press, St. Martin's Press.

Thomas, N. (1991). Entangled objects: Exchange, material culture, and colonialism in the Pacific. Cambridge: Harvard University Press.

Velthuis, O. (2003). Symbolic meanings of prices: Constructing the value of contemporary art in Amsterdam and New York galleries. Theory and Society, 32(2), 181-215.

Weber, M. (1964). Economy and society: an outline of interpretive sociology (2 volume set). Berkeley and Los Angeles: University of California Press.

Weber, M. (2001). The Protestant ethic and the spirit of capitalism. (trans: T. Parsons) with an introduction by A. Giddens. London and New York: Routledge.

Wherry, F. F. (2008). The social characterizations of price: The fool, the faithful, the frivolous, and the frugal. Sociological Theory, 26(4), 363-379.

Wherry, F. F. (2012). The culture of markets. Cambridge: Polity Press.

Wherry, F. F., \& Crosby, T. V. (2011). The cultural bank: Symbolic capital and local eocnomic development. In N. Bandelj \& F. F. Wherry (Eds.), The cultural wealth of nations (pp. 139-155). Stanford: Stanford University Press.

Woloson, W. A. (2007). In hock: Pawning in early America. Journal of the Early Republic, 27(1), 35-81.

Woloson, W. A. (2012). In hock: Pawning in America from independence through the great depression. Chicago: University of Chicago Press.

Zelizer, V. A. R. (1985). Pricing the priceless child : The changing social value of children. Princeton: Princeton University Press.

Zelizer, V. A. R. (1994). The social meaning of money. New York: Basic Books.

Zelizer, V. A. R. (2004). Circuits of commerce. In J. C. Alexander, G. T. Marx, \& C. L. Williams (Eds.), Self, social structure, and beliefs: Explorations in sociology. Berkeley: University of California Press.

Zelizer, V. A. R. (2005). The purchase of intimacy. Princeton: Princeton University Press. 
Anya Degenshein is a $\mathrm{PhD}$ candidate in Sociology at Northwestern University, where she is also a Presidential Fellow for the 2017-2019 academic years. Her dissertation project investigates the construction of risk through narratives of wrongdoing in domestic terrorism "entrapment" cases. 